\title{
Immunological and Translational Aspects of NK Cell-Based Antitumor Immunotherapies
}

\author{
Maxim Shevtsov ${ }^{1,2 *}$ and Gabriele Multhoff ${ }^{1,3}$ \\ ${ }^{1}$ Radiation Oncology, Klinikum rechts der Isar, Technische Universität München, Munich, Germany, ${ }^{2}$ Institute of Cytology of \\ the Russian Academy of Sciences (RAS), St. Petersburg, Russia, ${ }^{3}$ Experimental Immune Biology, Institute for innovative \\ Radiotherapy (iRT), Helmholtz Zentrum München, Neuherberg, Germany
}

OPEN ACCESS

Edited by:

Anne Mary Dickinson,

Newcastle University, UK

Reviewed by:

Stanislaw Stepkowski, University of Toledo, USA

Reem Al-Daccak,

French Institute of Health and Medical Research, France

*Correspondence:

Maxim Shevtsov

maxim.shevtsov@tum.de

Specialty section:

This article was submitted to Alloimmunity and Transplantation,

a section of the journal

Frontiers in Immunology

Received: 05 August 2016

Accepted: 25 October 2016

Published: 11 November 2016

Citation:

Shevtsov $M$ and Multhoff $G$ (2016) Immunological and Translational Aspects of NK

Cell-Based Antitumor Immunotherapies.

Front. Immunol. 7:492. doi: 10.3389/fimmu.2016.00492
Natural killer (NK) cells play a pivotal role in the first line of defense against cancer. NK cells that are deficient in CD3 and a clonal T cell receptor (TCR) can be subdivided into two major subtypes, CD56 ${ }^{\text {dim }}$ CD16 $6^{+}$cytotoxic and CD56 $6^{\text {bright }}$ CD16- immunoregulatory NK cells. Cytotoxic NK cells not only directly kill tumor cells without previous stimulation by cytotoxic effector molecules, such as perforin and granzymes or via death receptor interactions, but also act as regulatory cells for the immune system by secreting cytokines and chemokines. The aim of this review is to highlight therapeutic strategies utilizing autologous and allogenic NK cells, combinations of NK cells with monoclonal antibodies to induce antibody-dependent cellular cytotoxicity, or immune checkpoint inhibitors. Additionally, we discuss the use of chimeric antigen receptor-engineered NK cells in cancer immunotherapy.

Keywords: natural killer cell, immunotherapy, monoclonal antibody, antibody-dependent cellular cytotoxicity, checkpoint inhibitors, chimeric antigen receptor

\section{INTRODUCTION}

The adoptive transfer of ex vivo expanded and/or activated human natural killer (NK) cells represents a promising approach to treat cancer, as NK cells are specialized in the detection and elimination of "modified-self" (1). Apart from T cells, which are capable to recognize tumorassociated foreign antigens (TAA) only when presented on major histocompatibility complex antigen (MHC) molecules through the clonal T cell receptor (TCR), cells of the innate immune system [i.e., NK cells, lymphokine-activated killer (LAK) cells, and cytokine-induced killer (CIK) cells] can recognize and kill neoplastic cells even in the absence of human leukocyte antigen (HLA) and without prior stimulation. NK cells not only control tumor progression but are also engaged in reciprocal interactions with dendritic cells (DCs), macrophages, T cells, and endothelial cells (2). Clinical application of NK cells is an area of intense investigation not only in oncology, especially in hematological malignancies, including leukemia and lymphoma, but also in solid tumors such as ovarian cancer, sarcoma, hepatocellular carcinoma, glioblastoma, and many other types (3-9). Adoptive transfer of autologous or allogeneic NK cells might be superior to the currently widely used donor lymphocyte infusion, which predominantly contain $\mathrm{T}$ lymphocytes, due to the fact that NK cells provide the first line of defense and generally mediate less graft-versus-host disease (GvHD) than T cells $(10,11)$. An alternative for primary NK cells are well-characterized NK-like cell lines such as NK-92, KHYG-1, NKL, and NKG that show antitumor activities (12) and can be easily and reproducibly expanded and applied according to regulatory GMP standards $(13,14)$. 
Based on their tissue distribution and origin, NK cells are divided in bone marrow-derived adult conventional (peripheral) NK cells, thymic-derived, fetal-liver derived, liver resident, uterine-resident intestinal-resident NK cells (15). According to the 14th meeting of the Society of Natural Immunity, it is imperative to harmonize not only the donor source and ultimately donor selection but also the manufacturing and quality control of NK cells used in clinical trials (16). Adult conventional NK cells that are predominantly characterized by the expression of the homomeric adhesion molecule NCAM (CD56) and the low affinity receptor FcyRIII (CD16) and by lacking T cell specific markers such as CD3 and the TCR constitute around 5-20\% of peripheral blood lymphocytes. The activity of NK cells is defined by a fine balance of activating and inhibiting receptors belonging to different families including the killer-cell immunoglobulin-like receptors (KIRs), C-type lectin like or natural cytotoxicity class of receptors, and costimulatory receptors $(17,18)$. According to the surface expression density of CD56 and CD16, NK cells are subdivided into $\mathrm{CD} 56^{\text {bright }} \mathrm{CD} 16^{-}(90-95 \%)$ that are typically characterized by a low cytotoxicity and a high cytokine production and $\mathrm{CD} 56^{\text {dim }} \mathrm{CD} 16^{+}$cells $(5-10 \%)$ with a high cytotoxic activity and a low cytokine release profile (19). CD56 ${ }^{\mathrm{dim}} \mathrm{CD} 16^{+}$ NK cells that appear first after stem cell transplantation (SCT) or an IL-2-driven in vivo therapy are thought to represent a more immature NK cell type (20-22). This subpopulation is hypothesized to change its phenotype and differentiation state throughout its whole lifespan (23) and thus might be of special interest for clinical applications. $\mathrm{CD} 56^{\text {bright }} \mathrm{CD} 16^{-} \mathrm{NK}$ cells are considered to exert immunoregulatory functions through the production of Th1 cytokines [i.e., interferon gamma (IFN- $\gamma$ )] in response to interleukins such as IL-2, IL-12, IL-15, IL-18, and IL-21. They can rapidly proliferate, home to secondary lymphoid organs, and mediate the cross talk between the adaptive and innate immune system (24). In contrast, transforming growth factor- $\beta$ (TGF- $\beta$ ), IL-10, prostaglandin E2, indolamine 2,3-dioxygenase, adenosine (25), immune checkpoint inhibitors that are produced either by the tumor or its microenvironment as well as immunosuppressive cells such as regulatory $\mathrm{T}$ cells (Tregs) and myeloid-derived suppressor cells (MDSCs) can render the NK cell activity silent. Therefore, strategies that antagonize these factors and immunosuppressive cells, the avoidance of tumor hypoxia, the application of immune checkpoint inhibitor antibodies, might be beneficial to overcome the suppression of NK cells.

Activation and cytolytic activity of NK cells is dependent upon the activation of $\mathrm{NK}$ cell receptors including the natural cytotoxicity receptors (NKp30, NKp44, NKp46), C-type lectin receptors NKG2D, CD94/NKG2C, activatory KIRs, DNAX accessory molecule-1 (DNAM-1, CD226), and costimulatory receptors such as 2B4, NTB-A, CRACC, CD2, CD59, and CD16 (Figure 1A) $(26,27)$. Additionally, certain cytokines such as IL-2, IL-12, IL-15, IL-18, and IL-21 are known to stimulate both, the proliferative and cytolytic activity of NK cells (28). In order to avoid NK cell-mediated autoimmunity, their cytolytic activities are counterbalanced by the presence of inhibitory receptors such as inhibitory KIRs (22), CD94/NKG2A heterodimers, and checkpoint inhibitor receptors.

\section{ALLOGENIC AND AUTOLOGOUS NK CELL-BASED IMMUNOTHERAPIES}

\section{Allogenic NK Cell Approaches}

Allogeneic $\mathrm{T}$ cells have been shown to be very effective in the treatment of hematological diseases; however, this approach is often hampered by severe GvHD. Therefore, NK cells have been tested in haploidentical SCT settings. In multicenter phase I/II clinical trial, high-risk tumor patients were treated either with freshly isolated or IL-2-stimulated NK-donor lymphocyte infusion (NK-DLI) after haploidentical SCT without any signs of GvHD when less than $25 \times 10^{3} / \mathrm{kg} \mathrm{NK}$ cells were injected (29-31). It was also shown that IL-2-activated NK-DLI was more resistant toward immunosuppressive therapy compared to unstimulated NK-DLI (32), and that these effector cells were able to counteract the immunosuppressive activity of soluble MICA by reactivating NKG2D-mediated cytotoxicity $(33,34)$. The persistence of ex vivo haploidentical IL-2-activated and -expanded NK-DLIs ranges between 7 and 10 days in patients with AML, NHL, and ovarian cancer $(35,36)$. Allogeneic NK cells that were primed in a two-stage procedure with a leukemic cell line were found to show beneficial effects in patients with resistant AML in a phase I clinical trial (37), and the adoptive transfer of allogeneic CD56 ${ }^{\mathrm{dim}} \mathrm{CD} 16^{-} \mathrm{NK}-\mathrm{DLI}$ after haploidentical SCT showed promising results with respect to overall survival in a phase I/II clinical trial with patients with AML, ALL, CML, Hodgkin disease, and MDS (38). Another study using haploidentical KIR-ligand $\mathrm{CD} 56^{+} \mathrm{CD} 3^{-} \mathrm{NK}-\mathrm{DLI}$ in elderly AML patients showed an excellent safety profile and promising clinical responses (39).

Allogeneic NK cell therapies after haploidentical SCT show considerable progress within the last decade as determined in phase I/II clinical trials especially in patients with hematological diseases. A better understanding of the nature of NK cell receptors and activities (GvL versus GvHD), improved KIR typing, improved cell purification methods to obtain higher purities, and improved donor selections might improve the clinical outcome of NK cell-based therapies. In addition, further improvements may include novel cytokine cocktails (including IL-12, IL-15, IL-18, and IL-21), the combination of haploidentical NK cell therapies with standard therapies (radiochemotherapy) and/ or immune checkpoint inhibitor blockade, and the inclusion of chimeric antigen receptors (CARs) to NK cells. In contrast to hematological diseases, the impact of an NK cell-mediated therapy in solid tumors has to be analyzed in more detailed in further clinical trials.

\section{Autologous NK Cell Approaches}

Due to a large number of immune escape mechanisms of the tumor and its tumor microenvironment, NK cells of tumor patients are frequently tolerant to autologous tumors and have a lower cytotoxic potential compared to NK cells of healthy individuals (40). Ex vivo stimulation of NK cells of tumor patients with pro-inflammatory cytokines therefore could be beneficial in enhancing the antitumor immune activity mediated by NK cells. IL-2 (Proleukin) is widely applied and approved in various clinical protocols for the expansion and activation of 
A

NK cell stimulation approach

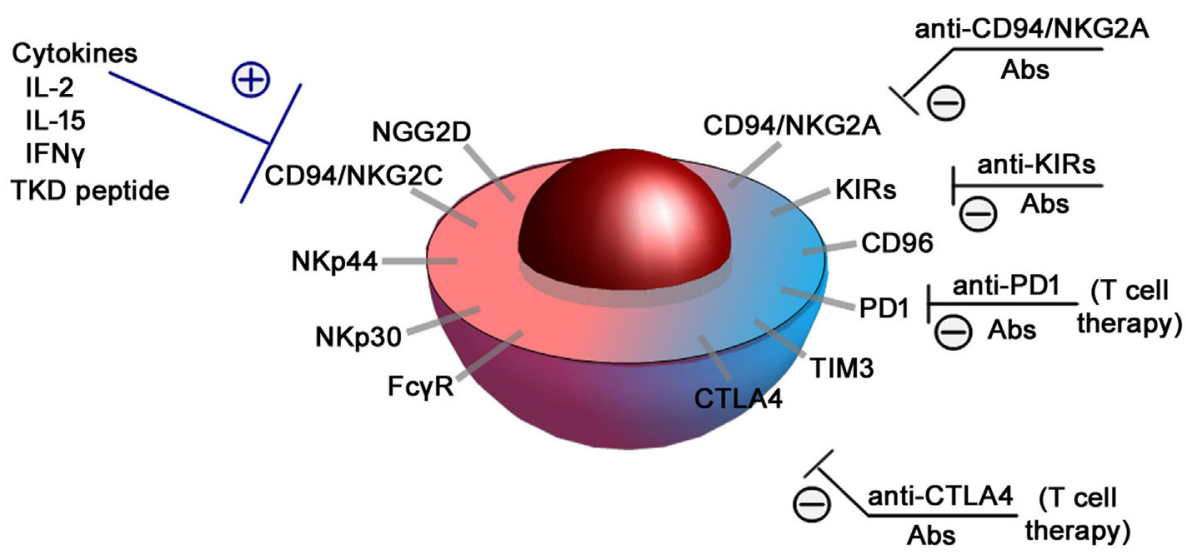

B

ADCC therapy
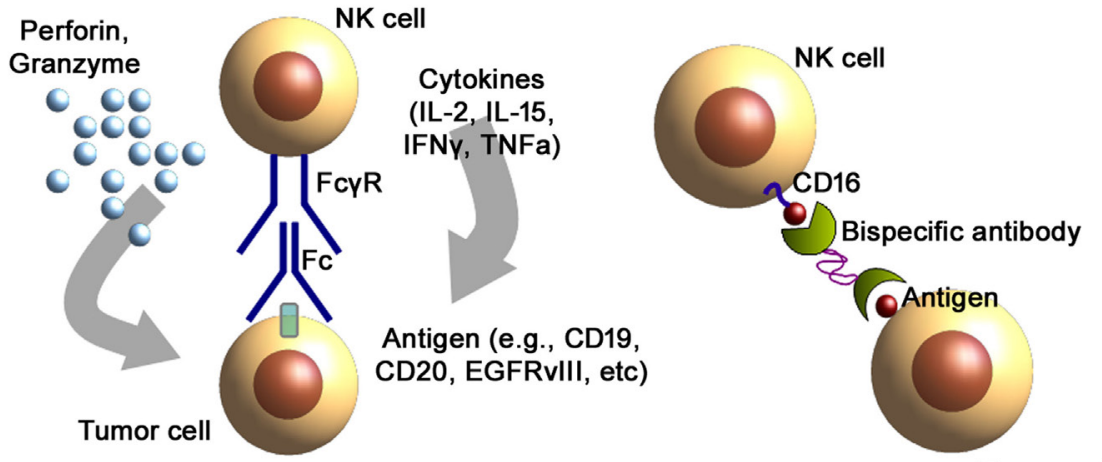

Tumor cell

C

CARs NK cells

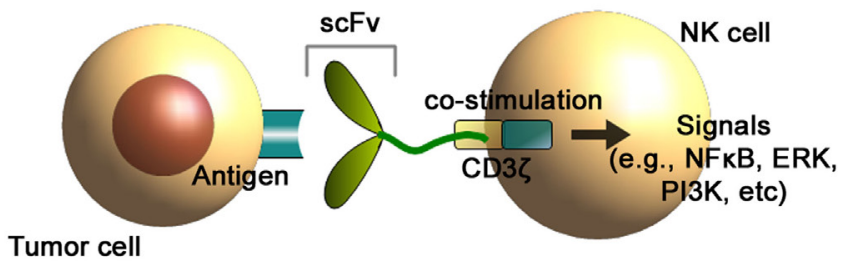

FIGURE 1 | NK cells-based immunotherapeutic concepts. (A) NK cell stimulation approach. Antibody-mediated blockade of the inhibitory receptors expressed on the cell membrane of NK cells as well as stimulation of the activating receptors results in an increased cytolytic activity of NK cells. (B) Antibody-dependent cellular cytotoxicity (ADCC) therapies. Binding of the FcyR to the Fc fragment of the antibody (left) results in the activation of NK cells and induces the release of effector molecules such as perforin and granzyme. Application of bispecific antibodies (right) directed against CD16 (on NK cells) and tumor antigens facilitate conjugate formation of NK cells with tumor cells. (C) Chimeric antigen receptor (CAR)-engineered NK cells. CAR consists of an external recognition domain [i.e., small chain variable fragment (scFv)] that recognizes the tumor-specific antigen, a transmembrane domain, and an intracellular signaling domain (CD3- $\zeta$ chain) that induces NK cell activation.

human effector T and NK cells (40-44), however, with varying success. Furthermore, in cases of a systemic application of high doses of IL-2, severe side effects are induced. A phase I clinical trial indicated that ex vivo low dose IL-2 plus Hsp70 peptideactivated, autologous NK cells have been found to be safe and well tolerated even at maximum doses of up to six complete leukapheresis products (45-47). In contrast to IL-2 alone, a stimulation of patient-derived NK cells with Hsp70 peptide plus IL-2 resulted in a reactivation of their cytolytic activity against Hsp70 membrane positive tumor cells (45). The stimulation of NK cells with cluster of differentiation 3 (CD3)-secreted cytokines resulted in a retardation of the growth of melanoma and breast tumors in mice with severe combined immunodeficiency (SCID). In a study by Lamas et al., it was demonstrated that 
leptin, a hormone-cytokine produced primarily by the adipose tissue, increased NK-92 cell metabolic activity and modulated NK cell cytotoxicity toward cancer cells due to an upregulated TNF-related apoptosis-inducing ligand (TRAIL) and IFN- $\gamma$ expression (48). Another attractive cytokine candidate that was shown to enhance in vitro and in vivo NK cell-mediated cytotoxicity and cytokine production is IL-15 $(49,50)$.

Multimodal therapy approaches in cancer therapy that employs chemotherapy with NK cell-based immunotherapy could also be potentially harmed by drug-mediated cytotoxicity toward NK cells. An interesting approach proposed by Dasgupta et al. showed that genetically engineered NK-92 cells that were resistant to both temozolomide and trimetrexate (51) showed significant therapeutic efficacy in a NOD/SCID $/ \gamma$ chain knockout (NSG) neuroblastoma mouse model with respect to tumor regression and survival rates in comparison to animals receiving non-engineered cell-based therapy and chemotherapy (51). Presumably, further combinations with other therapeutic approaches can further increase the efficacy of the adoptive transfer of autologous NK cells. Finkel et al. could show significantly enhanced antitumor effects mediated by NK cells following ionizing radiation and hyperthermia treatment. These data provide evidence that a combination of standard therapies such as radiotherapy, hyperthermia, and immunotherapy is feasible (52).

\section{ADCC-Based Immunotherapy}

Natural killer cells play a significant role in facilitating antitumor immunotherapies based on the application of the tumor-targeting monoclonal antibodies. One of the possible immunotherapeutic approaches is based on the antibodydependent cellular cytotoxicity (ADCC), which is mediated by NK cells (Figure 1B). NK cells are known to express both Fc $\gamma$ RIIC/CD32c and Fc $\gamma$ RIIIA/CD16a receptors that specifically bind the Fc region of IgG antibodies $(53,54)$. FcyRIIIA is usually associated with FcRI- $\gamma$ chains or CD3- $\zeta$ chains that are known to have immune tyrosine-based activating motifs (ITAM) in the cytoplasmic domain (55). Following activation of the Fc $\gamma$ R, these ITAM are phosphorylated (i.e., activation of signal transduction pathways including PI3K, NFkB, and ERK pathways) that leads to NK cell cytokine secretion and tumor cell lysis (56). ADCC of NK cells is based on (i) secretion of the cytotoxic granules (containing perforin and granzymes), (ii) TNF-mediated signaling, and (iii) pro-inflammatory cytokine release (i.e., IFN $\gamma$ ) (57).

Binding to the Fc fragment leads to the activation of cytotoxicity of NK cells that is utilized in the treatment of various types of cancers characterized by the overexpression of the certain tumor-associated antigens. To date, several ADCC therapies have been assessed in clinical trials including anti-CD20 mAbs (non-Hodgkin's lymphoma, chronic lymphocytic lymphoma), anti-ganglioside D2 (anti-GD2) mAbs (neuroblastoma, melanoma), anti-human epidermal growth factor (anti-HER2) mAbs (breast and gastric cancers), anti-epidermal growth factor receptor (anti-EGFR) mAbs (colorectal and head and neck cancer), and many other tumor entities (58-62). For the ADCC therapy, various types of antibodies (i.e., mouse antibodies, chimeric antibodies, and fully humanized antibodies) were applied. Thus, Veluchamy et al. (63) demonstrated that supplementary anti-EGFR-targeted therapy using monoclonal antibodies (i.e., cetuximab, panitumumab) significantly enhanced cytotoxic activity of NK cells toward EGFR-positive colorectal tumor cells. Furthermore, cetuximab, a chimeric mAb, was FDA approved for the treatment of EGFR-overexpressing metastatic colorectal cancer, metastatic non-small cell lung cancer, and head and neck cancer (64). The main limitation of the proposed ADCC approach is the source of tumor-specific target antigens. Presumably, combination of mAbs that target various tumor antigens could enhance the efficacy of the therapy. Also, the polymorphism of both FcyRIIC and Fc $\gamma$ RIIIA can influence the affinity of the Fc $\mathrm{R}$ toward IgG antibodies and as a result influence $\operatorname{ADCC}(65,66)$.

Alternative approaches to increase the specificity and killing activity of NK cells could be based on genetically engineered bispecific (BiKEs) and trispecific killer engagers (TriKEs) (67) (Figure 1B). These designed antibodies facilitate conjugate formation between NK cells and tumor cells. They usually bind both the tumor antigen and the FcyRIIIA/CD16 (68). Recently, a bispecific tetravalent antibody was introduced that targets both CD30 and CD16 for treatment of the relapsed Hodgkin lymphoma patients (69). Designed constructs exhibited superior cytotoxicity compared to conventional antibodies and were independent of the Fc gamma receptor IIIA (Fc $\gamma$ RIIIA) allotypes (70).

\section{Combination of Immune Checkpoint Inhibitor Blockade and NK Cell Therapy}

Application of the immune checkpoint inhibitor blockade could provide another approach for improving NK cell-based therapies (Figure 1A). In the study by Guo et al., introduction of the anti-PD1 blocking antibody to the NK cell therapy not only enhanced the in vitro activity of the cells (i.e., higher expression of NK activation receptors NKG2D, NKp44, and NKp30) but also augmented the therapeutic potency in the in vivo model of multiple myeloma in mice (71). Thus, treatment of autologous NK cells with blocking anti-PD-1 antibodies (pidilizumab) either alone or in combination with rituximab has been found to restore the cell-mediated cytolytic activity of NK cells in patients with multiple myeloma, renal cell carcinoma, and follicular lymphoma $(72,73)$.

Application of the anti-NKG2A antibodies could represent a novel immunotherapeutic approach in NK cell-based therapy. CD94/NKG2A is an inhibitory receptor that binds HLA-E. Many solid tumors and hemotological malignancies were shown to overexpress the HLA-E that could lead to the inhibition of the cytotoxic activity of NK cells and $\mathrm{CD}^{+}$cytotoxic T lymphocytes (74-77). Monalizumab (previously known as IPH2201) represents an anti-NKG2A checkpoint inhibitor that is currently tested in clinical trials including head and neck cancers, advanced solid tumors, ovarian cancers, and CLLs.

Another checkpoint inhibitory strategy is based on the application of blocking antibodies toward KIRs, which are activated through the MHC I class molecules present on tumor cells $(78,79)$. Anti-KIRs monoclonal antibodies (IPH2101) that 
target KIR2DL-1, -2, and -3 that are specific for HLA-C molecules were investigated in several phase I/II clinical trials (80, 81). Previous preclinical studies clearly confirmed the efficacy of the KIRs blockade on NK cells with respect to an increase in the cytotoxicity of the immune cells toward cancer cells $(82,83)$. Other immune checkpoint inhibitors [i.e., antibodies toward $\mathrm{T}$ cell immunoglobulin and mucin domain 3 (TIM-3), CD96], which are already used for the reactivation of exhausted $\mathrm{T}$ cells in melanoma patients, also demonstrated certain effects on NK cells, but the data are controversially discussed with regard to their therapeutic potential (84-86). The role of a TIM-3 blockade especially after cytokine activation of NK cells also show varying results. Further studies are necessary to elucidate the therapeutic role of the blockade of this checkpoint inhibitor, which is expressed on nearly all NK cells. The concomitant blockade of several inhibitors might increase the efficacy of the NK cellbased immunotherapy, although the induced side effects, such as skin rash, mucosa irritation, diarrhea, colitis, hepatotoxixicty, endocrinopasis, and general autoimmunity, should be considered with caution.

\section{CAR-ENGINEERED NK CELL THERAPY}

For a specific tumor, targeting the application of genetically engineered CARs for NK cells might provide a promising strategy. A CAR typically consists of an external recognition domain [i.e., small chain variable fragment $(\mathrm{scFv})$ ] that recognizes a tumor-specific antigen, a transmembrane domain, and an intracellular signaling domain that mediates NK cell activation. For signaling, usually the $\zeta$ chain of the TCR complex CD3 is employed (Figure 1C). At present, there are three generations of CARs in preclinical and clinical settings: (i) CARs with $\zeta$ chain of CD3; (ii) combination of CD3- $\zeta$ chain with coactivating proteins (e.g., CD28, CD137, and CD134); and (iii) application of CD3- $\zeta$ with multiple coactivating domains (87-89). Target cell lines for the development of CARs can be established NK-like cell lines (1) (e.g., NK-92 cells) (14), freshly isolated peripheral blood NK cells $(2,90)$, or induced pluripotent stem cells (iPSCs) (3) or after subsequent differentiation into mature NK cells $(91,92)$.

Modified NK cells were shown to significantly enhance antitumor immune responses. Thus, to facilitate selective target cell recognition and enhanced specific cytotoxicity against $\mathrm{B}$-acute lymphoblastic leukemia (B-ALL), the authors transduced the cells with a lentiviral vector encoding a CAR that carry a composite CD28-CD3ל domain for signaling and a CD19-specific scFv antibody fragment for cell binding (CAR 63.28.z) (93). Treatment with CAR-modified NK cells in a xenograft model resulted in complete and durable molecular remissions of established primary B-ALL (93). To date, several NK-92-based cell lines have been engineered that express a number of different CARs including CD138 or CS1 (anti-multiple myeloma), human epidermal growth factor receptor 2 (HER2) for solid tumors, CD20, CD19 for B cell leukemias, wild-type EGFR and mutant form EGFRvIII for breast cancer patients with brain metastasis, glioblastoma, and ganglioside protein D2 (GD2) for neuroectodermal tumors (3, 94-104).
In summary, many preclinical studies clearly demonstrate therapeutic efficacy of CAR-engineered NK cell-based therapies. However, only few studies compare the efficacy of first-, second-, and third-generation CARs. Another aspect is the choice of the source of NK cells. NK cell lines provide an interesting alternative for peripheral blood-derived NK cells because there is an unlimited availability. However, the density of activatory NK cell receptors on NK cell lines is generally lower, an irradiation prior infusion is necessary, and therefore the in vivo persistence is reduced. In contrast, peripheral blood NK cells carry a wider range of activating receptors (i.e., CD16, NKp44, and NKp46) and could be administered without prior irradiation and thus might improve the clinical effectiveness of the cell therapy (105). Another challenge of genetically engineered CARs is the choice of the tumor target. Future clinical applications might utilize several targets to increase the specificity of CAR-based therapies. Modification of the NK cells that makes them insensitive to the immunosuppressive tumor milieu could further increase the efficacy of CAR-NK cells to kill solid tumors that are resistant to NK cell-based immunotherapy.

Alternative approaches are based on the NK cell line NK-92 that is insensitive toward immunosuppressive cytokines (e.g., TGF- $\beta$ ). In a study by Yang et al., it was shown that adoptive transfer of a dominant negative TGF- $\beta$ type II receptor (DNT $\beta$ RII) into NK cells significantly decreased tumor proliferation in a lung cancer mouse model (106). Moreover, as recently shown by the group of Genßler et al., genetically engineering NK cells have been shown to overcome tumor heterogeneity by targeting different tumor targets (107). Dual-specific NK cells that recognize both EGFR and EGFRvIII antigens are superior to the monospecific CAR-NK cells in the therapy of glioblastoma (107).

\section{CONCLUSION}

Natural killer cells-based immunotherapies provide a promising approach that could be employed as an adjuvant anticancer therapy. Most likely, a combination of ex vivo cytokine-stimulated autologous or allogenic NK cells with other immunomodulators (i.e., monoclonal antibodies, immune checkpoint inhibitor blockade) and/or standard therapies (i.e., chemo- and radiotherapy) might exert beneficial effects in the treatment of cancer. CAR-engineered NK cells represent a novel immunotherapeutic strategy that could increase the specificity NK cells. Although most NK cell-based therapies are presently in the preclinical phase, recent advances in the therapeutic strategies as well as modifications of the NK cell biology will significantly contribute to the clinical efficacy of NK cell-based therapeutic concepts.

\section{AUTHOR CONTRIBUTIONS}

MS and GM wrote and approved the final version of the manuscript.

\section{ACKNOWLEDGMENTS}

The authors thank Nang-Jong Lee for figures preparation and Anett Lange for excellent editorial assistance. 


\section{FUNDING}

The study was supported from the Russian Foundation for Basic Research 15-08-08148A, by a grant of the Russian Science Foundation 14-50-00068 and by the Federal Agency of Scientific Organizations, Russia, and by a DFG grant

\section{REFERENCES}

1. Perica K, Varela JC, Oelke M, Schneck J. Adoptive T cell immunotherapy for cancer. Rambam Maimonides Med J (2015) 6:e0004. doi:10.5041/ RMMJ.10179

2. Vivier E, Tomasello E, Baratin M, Walzer T, Ugolini S. Functions of natural killer cells. Nat Immunol (2008) 9:503-10. doi:10.1038/ni1582

3. Suck G, Linn YC, Tonn T. Natural killer cells for therapy of leukemia. Transfus Med Hemother (2016) 43:89-95. doi:10.1159/000445325

4. Handgretinger R, Lang P, Andre MC. Exploitation of natural killer cells for the treatment of acute leukemia. Blood (2016) 127:3341-9. doi:10.1182/ blood-2015-12-629055

5. Mittica G, Capellero S, Genta S, Cagnazzo C, Aglietta M, Sangiolo D, et al. Adoptive immunotherapy against ovarian cancer. J Ovarian Res (2016) 9:30. doi:10.1186/s13048-016-0236-9

6. Mesiano G, Leuci V, Giraudo L, Gammaitoni L, Carnevale Schianca F, Cangemi M, et al. Adoptive immunotherapy against sarcomas. Expert Opin Biol Ther (2015) 15:517-28. doi:10.1517/14712598.2015.987121

7. Qian L, Wang N, Tian H, Jin H, Zhao H, Niu C, et al. Dual effects of cellular immunotherapy in inhibition of virus replication and prolongation of survival in HCV-positive hepatocellular carcinoma patients. J Immunol Res (2016) 2016:6837241. doi:10.1155/2016/6837241

8. Zhang C, Burger MC, Jennewein L, Genssler S, Schonfeld K, Zeiner P, et al. ErbB2/HER2-specific NK cells for targeted therapy of glioblastoma. J Natl Cancer Inst (2016) 108(5):djv375. doi:10.1093/jnci/djv375

9. Rezvani K, Rouce RH. The application of natural killer cell immunotherapy for the treatment of cancer. Front Immunol (2015) 6:578. doi:10.3389/ fimmu.2015.00578

10. Ruggeri L, Capanni M, Urbani E, Perruccio K, Shlomchik WD, Tosti A, et al. Effectiveness of donor natural killer cell alloreactivity in mismatched hematopoietic transplants. Science (2002) 295:2097-100. doi:10.1126/ science. 1068440

11. Locatelli F, Pende D, Mingari MC, Bertaina A, Falco M, Moretta A, et al. Cellular and molecular basis of haploidentical hematopoietic stem cell transplantation in the successful treatment of high-risk leukemias: role of alloreactive NK cells. Front Immunol (2013) 4:15. doi:10.3389/fimmu. 2013.00015

12. Yagita $M$, Huang CL, Umehara $H$, Matsuo $Y$, Tabata R, Miyake $M$, et al. A novel natural killer cell line (KHYG-1) from a patient with aggressive natural killer cell leukemia carrying a p53 point mutation. Leukemia (2000) 14:922-30. doi:10.1038/sj.leu.2401769

13. Suck G, Odendahl M, Nowakowska P, Seidl C, Wels WS, Klingemann HG, et al. NK-92: an 'off-the-shelf therapeutic' for adoptive natural killer cell-based cancer immunotherapy. Cancer Immunol Immunother (2016) 65:485-92. doi:10.1007/s00262-015-1761-x

14. Tonn T, Schwabe D, Klingemann HG, Becker S, Esser R, Koehl U, et al. Treatment of patients with advanced cancer with the natural killer cell line NK-92. Cytotherapy (2013) 15:1563-70. doi:10.1016/j.jcyt.2013.06.017

15. Carotta S. Targeting NK cells for anticancer immunotherapy: clinical and preclinical approaches. Front Immunol (2016) 7:152. doi:10.3389/ fimmu.2016.00152

16. Koehl U, Kalberer C, Spanholtz J, Lee DA, Miller JS, Cooley S, et al. Advances in clinical NK cell studies: donor selection, manufacturing and quality control. Oncoimmunology (2016) 5:e1115178. doi:10.1080/2162402X.2015. 1115178

17. Farag SS, Caligiuri MA. Human natural killer cell development and biology. Blood Rev (2006) 20:123-37. doi:10.1016/j.blre.2005.10.001

18. Moretta A, Bottino C, Vitale M, Pende D, Cantoni C, Mingari MC, et al. Activating receptors and coreceptors involved in human natural killer
(SFB824/2), the Bundesministerium für Forschung und Technologie (BMBF 02NUK038A, 01GU0823, DKTK-ROG), EU CELLEUROPE (EU 315963). This work was also supported by the German Research Foundation (DFG) and the Technische Universität München within the funding programme Open Access Publishing.

cell-mediated cytolysis. Annu Rev Immunol (2001) 19:197-223. doi:10.1146/ annurev.immunol.19.1.197

19. Vivier E, Ugolini S, Blaise D, Chabannon C, Brossay L. Targeting natural killer cells and natural killer T cells in cancer. Nat Rev Immunol (2012) 12:239-52. doi:10.1038/nri3174

20. Cooper MA, Fehniger TA, Caligiuri MA. The biology of human natural killer-cell subsets. Trends Immunol (2001) 22:633-40. doi:10.1016/ S1471-4906(01)02060-9

21. Jacobs R, Stoll M, Stratmann G, Leo R, Link H, Schmidt RE. CD16- CD56+ natural killer cells after bone marrow transplantation. Blood (1992) 79:3239-44

22. Vukicevic M, Chalandon Y, Helg C, Matthes T, Dantin C, Huard B, et al. CD56bright NK cells after hematopoietic stem cell transplantation are activated mature NK cells that expand in patients with low numbers of T cells Eur J Immunol (2010) 40:3246-54. doi:10.1002/eji.200940016

23. Bjorkstrom NK, Riese P, Heuts F, Andersson S, Fauriat C, Ivarsson MA, et al. Expression patterns of NKG2A, KIR, and CD57 define a process of CD56dim NK-cell differentiation uncoupled from NK-cell education. Blood (2010) 116:3853-64. doi:10.1182/blood-2010-04-281675

24. Poli A, Michel T, Theresine M, Andres E, Hentges F, Zimmer J. CD56bright natural killer (NK) cells: an important NK cell subset. Immunology (2009) 126:458-65. doi:10.1111/j.1365-2567.2008.03027.x

25. Vaupel P, Multhoff G. Adenosine can thwart anti-tumor immune responses elicited by radiotherapy: therapeutic strategies alleviating protumor ADO activities. Strahlenther Onkol (2016) 192:279-87. doi:10.1007/ s00066-016-0948-1

26. Yokoyama WM, Plougastel BF. Immune functions encoded by the natural killer gene complex. Nat Rev Immunol (2003) 3:304-16. doi:10.1038/ nri1055

27. Martinet L, Smyth MJ. Balancing natural killer cell activation through paired receptors. Nat Rev Immunol (2015) 15:243-54. doi:10.1038/nri3799

28. Marcais A, Viel S, Grau M, Henry T, Marvel J, Walzer T. Regulation of mouse NK cell development and function by cytokines. Front Immunol (2013) 4:450. doi:10.3389/fimmu.2013.00450

29. Stern M, Passweg JR, Meyer-Monard S, Esser R, Tonn T, Soerensen J, et al. Pre-emptive immunotherapy with purified natural killer cells after haploidentical SCT: a prospective phase II study in two centers. Bone Marrow Transplant (2013) 48:433-8. doi:10.1038/bmt.2012.162

30. Huenecke S, Zimmermann SY, Kloess S, Esser R, Brinkmann A, Tramsen L, et al. IL-2-driven regulation of NK cell receptors with regard to the distribution of CD16+ and CD16- subpopulations and in vivo influence after haploidentical NK cell infusion. J Immunother (2010) 33:200-10. doi:10.1097/ CJI.0b013e3181bb46f7

31. Brehm C, Huenecke S, Quaiser A, Esser R, Bremm M, Kloess S, et al. IL-2 stimulated but not unstimulated NK cells induce selective disappearance of peripheral blood cells: concomitant results to a phase I/II study. PLoS One (2011) 6:e27351. doi:10.1371/journal.pone.0027351

32. Brehm C, Huenecke S, Esser R, Kloess S, Quaiser A, Betz S, et al. Interleukin2-stimulated natural killer cells are less susceptible to mycophenolate mofetil than non-activated NK cells: possible consequences for immunotherapy. Cancer Immunol Immunother (2014) 63:821-33. doi:10.1007/ s00262-014-1556-5

33. Kloess S, Huenecke S, Piechulek D, Esser R, Koch J, Brehm C, et al. IL-2activated haploidentical NK cells restore NKG2D-mediated NK-cell cytotoxicity in neuroblastoma patients by scavenging of plasma MICA. Eur J Immunol (2010) 40:3255-67. doi:10.1002/eji.201040568

34. Ullrich E, Koch J, Cerwenka A, Steinle A. New prospects on the NKG2D/ NKG2DL system for oncology. Oncoimmunology (2013) 2:e26097. doi:10.4161/onci.26097 
35. Geller MA, Ivy JJ, Ghebre R, Downs LS Jr, Judson PL, Carson LF, et al. A phase II trial of carboplatin and docetaxel followed by radiotherapy given in a "Sandwich" method for stage III, IV, and recurrent endometrial cancer. Gynecol Oncol (2011) 121:112-7. doi:10.1016/j.ygyno.2010. 12.338

36. Bachanova V, Burns LJ, McKenna DH, Curtsinger J, Panoskaltsis-Mortari A, Lindgren BR, et al. Allogeneic natural killer cells for refractory lymphoma. Cancer Immunol Immunother (2010) 59:1739-44. doi:10.1007/ s00262-010-0896-z

37. Kottaridis PD, North J, Tsirogianni M, Marden C, Samuel ER, Jide-Banwo $\mathrm{S}$, et al. Two-stage priming of allogeneic natural killer cells for the treatment of patients with acute myeloid leukemia: a phase I trial. PLoS One (2015) 10:e0123416. doi:10.1371/journal.pone.0123416

38. Penack O, Gentilini C, Fischer L, Asemissen AM, Scheibenbogen C, Thiel E, et al. CD56dimCD16neg cells are responsible for natural cytotoxicity against tumor targets. Leukemia (2005) 19:835-40. doi:10.1038/sj.leu. 2403704

39. Arpinati $M$, Curti A. Immunotherapy in acute myeloid leukemia. Immunotherapy (2014) 6:95-106. doi:10.2217/imt.13.152

40. Pegram HJ, Andrews DM, Smyth MJ, Darcy PK, Kershaw MH. Activating and inhibitory receptors of natural killer cells. Immunol Cell Biol (2011) 89:216-24. doi:10.1038/icb.2010.78

41. Burns LJ, Weisdorf DJ, DeFor TE, Vesole DH, Repka TL, Blazar BR, et al. IL-2-based immunotherapy after autologous transplantation for lymphoma and breast cancer induces immune activation and cytokine release: a phase I/II trial. Bone Marrow Transplant (2003) 32:177-86. doi:10.1038/ sj.bmt. 1704086

42. Berg M, Lundqvist A, McCoy P Jr, Samsel L, Fan Y, Tawab A, et al. Clinical-grade ex vivo-expanded human natural killer cells up-regulate activating receptors and death receptor ligands and have enhanced cytolytic activity against tumor cells. Cytotherapy (2009) 11:341-55. doi:10.1080/ 14653240902807034

43. Fujisaki H, Kakuda H, Shimasaki N, Imai C, Ma J, Lockey T, et al. Expansion of highly cytotoxic human natural killer cells for cancer cell therapy. Cancer Res (2009) 69:4010-7. doi:10.1158/0008-5472.CAN08-3712

44. Linn YC, Niam M, Chu S, Choong A, Yong HX, Heng KK, et al. The antitumour activity of allogeneic cytokine-induced killer cells in patients who relapse after allogeneic transplant for haematological malignancies. Bone Marrow Transplant (2012) 47:957-66. doi:10.1038/bmt.2011.202

45. Krause SW, Gastpar R, Andreesen R, Gross C, Ullrich H, Thonigs G, et al. Treatment of colon and lung cancer patients with ex vivo heat shock protein 70-peptide-activated, autologous natural killer cells: a clinical phase I trial. Clin Cancer Res (2004) 10:3699-707.

46. Specht HM, Ahrens N, Blankenstein C, Duell T, Fietkau R, Gaipl US, et al. Heat shock protein 70 (Hsp70) peptide activated natural killer (NK) cells for the treatment of patients with non-small cell lung cancer (NSCLC) after radiochemotherapy (RCTx) - from preclinical studies to a clinical phase II trial. Front Immunol (2015) 6:162. doi:10.3389/fimmu. 2015.00162

47. Gunther S, Ostheimer C, Stangl S, Specht HM, Mozes P, Jesinghaus M, et al. Correlation of Hsp70 serum levels with gross tumor volume and composition of lymphocyte subpopulations in patients with squamous cell and adeno non-small cell lung cancer. Front Immunol (2015) 6:556. doi:10.3389/ fimmu. 2015.00556

48. Lamas B, Goncalves-Mendes N, Nachat-Kappes R, Rossary A, CaldefieChezet F, Vasson MP, et al. Leptin modulates dose-dependently the metabolic and cytolytic activities of NK-92 cells. J Cell Physiol (2013) 228:1202-9. doi:10.1002/jcp. 24273

49. Carson WE, Giri JG, Lindemann MJ, Linett ML, Ahdieh M, Paxton R, et al. Interleukin (IL) 15 is a novel cytokine that activates human natural killer cells via components of the IL-2 receptor. J Exp Med (1994) 180:1395-403. doi:10.1084/jem.180.4.1395

50. Conlon KC, Lugli E, Welles HC, Rosenberg SA, Fojo AT, Morris JC, et al. Redistribution, hyperproliferation, activation of natural killer cells and CD8 T cells, and cytokine production during first-in-human clinical trial of recombinant human interleukin-15 in patients with cancer. J Clin Oncol (2015) 33:74-82. doi:10.1200/JCO.2014.57.3329
51. Dasgupta A, Shields JE, Spencer HT. Treatment of a solid tumor using engineered drug-resistant immunocompetent cells and cytotoxic chemotherapy. Hum Gene Ther (2012) 23:711-21. doi:10.1089/hum.2011.172

52. Finkel P, Frey B, Mayer F, Bosl K, Werthmoller N, Mackensen A, et al. The dual role of NK cells in anti-tumor reactions triggered by ionizing radiation in combination with hyperthermia. Oncoimmunology (2016) 5:e1101206. doi:10.1080/2162402X.2015.1101206

53. Lanier LL, Ruitenberg JJ, Phillips JH. Functional and biochemical analysis of CD16 antigen on natural killer cells and granulocytes. J Immunol (1988) 141:3478-85.

54. Morel PA, Ernst LK, Metes D. Functional CD32 molecules on human NK cells. Leuk Lymphoma (1999) 35:47-56. doi:10.3109/10428199909145704

55. Lanier LL. Up on the tightrope: natural killer cell activation and inhibition. Nat Immunol (2008) 9:495-502. doi:10.1038/ni1581

56. Smyth MJ, Cretney E, Kelly JM, Westwood JA, Street SE, Yagita H, et al. Activation of NK cell cytotoxicity. Mol Immunol (2005) 42:501-10. doi:10.1016/j.molimm.2004.07.034

57. Srivastava RM, Lee SC, Andrade Filho PA, Lord CA, Jie HB, Davidson HC, et al. Cetuximab-activated natural killer and dendritic cells collaborate to trigger tumor antigen-specific T-cell immunity in head and neck cancer patients. Clin Cancer Res (2013) 19:1858-72. doi:10.1158/1078-0432. CCR-12-2426

58. Cartron G, Dacheux L, Salles G, Solal-Celigny P, Bardos P, Colombat P, et al. Therapeutic activity of humanized anti-CD20 monoclonal antibody and polymorphism in IgG Fc receptor FcgammaRIIIa gene. Blood (2002) 99:754-8. doi:10.1182/blood.V99.3.754

59. Goede V, Fischer K, Busch R, Engelke A, Eichhorst B, Wendtner CM, et al. Obinutuzumab plus chlorambucil in patients with CLL and coexisting conditions. N Engl J Med (2014) 370:1101-10. doi:10.1056/NEJMoa 1313984

60. Yu AL, Gilman AL, Ozkaynak MF, London WB, Kreissman SG, Chen HX, et al. Anti-GD2 antibody with GM-CSF, interleukin-2, and isotretinoin for neuroblastoma. N Engl J Med (2010) 363:1324-34. doi:10.1056/ NEJMoa0911123

61. Junttila TT, Parsons K, Olsson C, Lu Y, Xin Y, Theriault J, et al. Superior in vivo efficacy of afucosylated trastuzumab in the treatment of HER2amplified breast cancer. Cancer Res (2010) 70:4481-9. doi:10.1158/00085472.CAN-09-3704

62. Messersmith WA, Ahnen DJ. Targeting EGFR in colorectal cancer. $N$ Engl I Med (2008) 359:1834-6. doi:10.1056/NEJMe0806778

63. Veluchamy JP, Spanholtz J, Tordoir M, Thijssen VL, Heideman DA, Verheul $\mathrm{HM}$, et al. Combination of NK cells and cetuximab to enhance anti-tumor responses in RAS mutant metastatic colorectal cancer. PLoS One (2016) 11:e0157830. doi:10.1371/journal.pone.0157830

64. Schroder K, Hertzog PJ, Ravasi T, Hume DA. Interferon-gamma: an overview of signals, mechanisms and functions. J Leukoc Biol (2004) 75:163-89. doi:10.1189/jlb.0603252

65. Niwa R, Hatanaka S, Shoji-Hosaka E, Sakurada M, Kobayashi Y, Uehara A, et al. Enhancement of the antibody-dependent cellular cytotoxicity of low-fucose IgG1 Is independent of FcgammaRIIIa functional polymorphism. Clin Cancer Res (2004) 10:6248-55. doi:10.1158/1078-0432.CCR04-0850

66. Bibeau F, Lopez-Crapez E, Di Fiore F, Thezenas S, Ychou M, Blanchard F, et al. Impact of Fc \{gamma\}RIIa-Fc \{gamma\}RIIIa polymorphisms and KRAS mutations on the clinical outcome of patients with metastatic colorectal cancer treated with cetuximab plus irinotecan. J Clin Oncol (2009) 27:1122-9. doi:10.1200/JCO.2008.18.0463

67. Kontermann RE, Brinkmann U. Bispecific antibodies. Drug Discov Today (2015) 20:838-47. doi:10.1016/j.drudis.2015.02.008

68. Spiess C, Zhai Q, Carter PJ. Alternative molecular formats and therapeutic applications for bispecific antibodies. Mol Immunol (2015) 67:95-106. doi:10.1016/j.molimm.2015.01.003

69. Rothe A, Sasse S, Topp MS, Eichenauer DA, Hummel H, Reiners KS, et al. A phase 1 study of the bispecific anti-CD30/CD16A antibody construct AFM13 in patients with relapsed or refractory Hodgkin lymphoma. Blood (2015) 125:4024-31. doi:10.1182/blood-2014-12-614636

70. Reusch U, Duell J, Ellwanger K, Herbrecht C, Knackmuss SH, Fucek I, et al. A tetravalent bispecific TandAb (CD19/CD3), AFM11, efficiently recruits 
T cells for the potent lysis of CD19(+) tumor cells. MAbs (2015) 7:584-604. doi:10.1080/19420862.2015.1029216

71. Guo Y, Feng X, Jiang Y, Shi X, Xing X, Liu X, et al. PD1 blockade enhances cytotoxicity of in vitro expanded natural killer cells towards myeloma cells. Oncotarget (2016). doi:10.18632/oncotarget.10235

72. Benson DM Jr, Bakan CE, Mishra A, Hofmeister CC, Efebera Y, Becknell $\mathrm{B}$, et al. The PD-1/PD-L1 axis modulates the natural killer cell versus multiple myeloma effect: a therapeutic target for CT-011, a novel monoclonal anti-PD-1 antibody. Blood (2010) 116:2286-94. doi:10.1182/blood-2010-02271874

73. Westin JR, Chu F, Zhang M, Fayad LE, Kwak LW, Fowler N, et al. Safety and activity of PD1 blockade by pidilizumab in combination with rituximab in patients with relapsed follicular lymphoma: a single group, open-label, phase 2 trial. Lancet Oncol (2014) 15:69-77. doi:10.1016/S1470-2045(13) 70551-5

74. Lo Monaco E, Tremante E, Cerboni C, Melucci E, Sibilio L, Zingoni A, et al. Human leukocyte antigen E contributes to protect tumor cells from lysis by natural killer cells. Neoplasia (2011) 13:822-30. doi:10.1593/neo. 101684

75. Fruci D, Lo Monaco E, Cifaldi L, Locatelli F, Tremante E, Benevolo M, et al. T and NK cells: two sides of tumor immunoevasion. J Transl Med (2013) 11:30. doi:10.1186/1479-5876-11-30

76. Bossard C, Bezieau S, Matysiak-Budnik T, Volteau C, Laboisse CL, Jotereau F, et al. HLA-E/beta2 microglobulin overexpression in colorectal cancer is associated with recruitment of inhibitory immune cells and tumor progression. Int J Cancer (2012) 131:855-63. doi:10.1002/ijc.26453

77. Pace E, Di Sano C, Ferraro M, Tipa A, Olivieri D, Spatafora M, et al. Altered CD94/NKG2A and perforin expression reduce the cytotoxic activity in malignant pleural effusions. Eur J Cancer (2011) 47:296-304. doi:10.1016/j. ejca.2010.09.001

78. Thielens A, Vivier E, Romagne F. NK cell MHC class I specific receptors (KIR): from biology to clinical intervention. Curr Opin Immunol (2012) 24:239-45. doi:10.1016/j.coi.2012.01.001

79. Raulet DH, Vance RE. Self-tolerance of natural killer cells. Nat Rev Immunol (2006) 6:520-31. doi:10.1038/nri1863

80. Vey N, Bourhis JH, Boissel N, Bordessoule D, Prebet T, Charbonnier A, et al. A phase 1 trial of the anti-inhibitory KIR mAb IPH2101 for AML in complete remission. Blood (2012) 120:4317-23. doi:10.1182/blood-2012-06437558

81. Benson DM Jr, Cohen AD, Jagannath S, Munshi NC, Spitzer G, Hofmeister CC, et al. A phase I trial of the anti-KIR antibody IPH2101 and lenalidomide in patients with relapsed/refractory multiple myeloma. Clin Cancer Res (2015) 21:4055-61. doi:10.1158/1078-0432.CCR-15-0304

82. Romagne F, Andre P, Spee P, Zahn S, Anfossi N, Gauthier L, et al. Preclinical characterization of 1-7F9, a novel human anti-KIR receptor therapeutic antibody that augments natural killer-mediated killing of tumor cells. Blood (2009) 114:2667-77. doi:10.1182/blood-2009-02-206532

83. Kohrt HE, Thielens A, Marabelle A, Sagiv-Barfi I, Sola C, Chanuc F, et al. Anti-KIR antibody enhancement of anti-lymphoma activity of natural killer cells as monotherapy and in combination with anti-CD20 antibodies. Blood (2014) 123:678-86. doi:10.1182/blood-2013-08-519199

84. Gleason MK, Lenvik TR, McCullar V, Felices M, O'Brien MS, Cooley SA, et al. Tim-3 is an inducible human natural killer cell receptor that enhances interferon gamma production in response to galectin-9. Blood (2012) 119:3064-72. doi:10.1182/blood-2011-06-360321

85. Ndhlovu LC, Lopez-Verges S, Barbour JD, Jones RB, Jha AR, Long BR, et al. Tim-3 marks human natural killer cell maturation and suppresses cell-mediated cytotoxicity. Blood (2012) 119:3734-43. doi:10.1182/blood2011-11-392951

86. Chan CJ, Martinet L, Gilfillan S, Souza-Fonseca-Guimaraes F, Chow MT, Town L, et al. The receptors CD96 and CD226 oppose each other in the regulation of natural killer cell functions. Nat Immunol (2014) 15:431-8. doi: $10.1038 /$ ni. 2850

87. Gross G, Waks T, Eshhar Z. Expression of immunoglobulin-T-cell receptor chimeric molecules as functional receptors with antibody-type specificity. Proc Natl Acad Sci U S A (1989) 86:10024-8. doi:10.1073/pnas.86. 24.10024
88. Sadelain M, Brentjens R, Riviere I. The basic principles of chimeric antigen receptor design. Cancer Discov (2013) 3:388-98. doi:10.1158/2159-8290. CD-12-0548

89. Jena B, Moyes JS, Huls H, Cooper LJ. Driving CAR-based T-cell therapy to success. Curr Hematol Malig Rep (2014) 9:50-6. doi:10.1007/s11899-0130197-7

90. Spanholtz J, Preijers F, Tordoir M, Trilsbeek C, Paardekooper J, de Witte T, et al. Clinical-grade generation of active NK cells from cord blood hematopoietic progenitor cells for immunotherapy using a closed-system culture process. PLoS One (2011) 6:e20740. doi:10.1371/journal.pone.0020740

91. Ni Z, Knorr DA, Kaufman DS. Hematopoietic and nature killer cell development from human pluripotent stem cells. Methods Mol Biol (2013) 1029:33-41. doi:10.1007/978-1-62703-478-4_3

92. Woll PS, Grzywacz B, Tian X, Marcus RK, Knorr DA, Verneris MR, et al. Human embryonic stem cells differentiate into a homogeneous population of natural killer cells with potent in vivo anti-tumor activity. Blood (2009) 113:6094-101. doi:10.1182/blood-2008-06-165225

93. Oelsner S, Wagner J, Friede ME, Pfirrmann V, Genssler S, Rettinger E, et al. Chimeric antigen receptor-engineered cytokine-induced killer cells overcome treatment resistance of pre-B-cell acute lymphoblastic leukemia and enhance survival. Int J Cancer (2016) 139:1799-809. doi:10.1002/ijc.30217

94. Chu J, Deng Y, Benson DM, He S, Hughes T, Zhang J, et al. CS1-specific chimeric antigen receptor (CAR)-engineered natural killer cells enhance in vitro and in vivo anti-tumor activity against human multiple myeloma. Leukemia (2014) 28:917-27. doi:10.1038/leu.2013.279

95. Chen X, Han J, Chu J, Zhang L, Zhang J, Chen C, et al. A combinational therapy of EGFR-CAR NK cells and oncolytic herpes simplex virus 1 for breast cancer brain metastases. Oncotarget (2016) 7:27764-77. doi:10.18632/ oncotarget. 8526

96. Romanski A, Uherek C, Bug G, Seifried E, Klingemann H, Wels WS, et al. CD19-CAR engineered NK-92 cells are sufficient to overcome NK cell resistance in B-cell malignancies. J Cell Mol Med (2016) 20:1287-94. doi:10.1111/ jcmm. 12810

97. Han J, Chu J, Keung Chan W, Zhang J, Wang Y, Cohen JB, et al. CARengineered NK cells targeting wild-type EGFR and EGFRvIII enhance killing of glioblastoma and patient-derived glioblastoma stem cells. Sci Rep (2015) 5:11483. doi:10.1038/srep11483

98. Esser R, Muller T, Stefes D, Kloess S, Seidel D, Gillies SD, et al. NK cells engineered to express a GD2-specific antigen receptor display built-in ADCC-like activity against tumour cells of neuroectodermal origin. J Cell Mol Med (2012) 16:569-81. doi:10.1111/j.1582-4934.2011.01343.x

99. Muller T, Uherek C, Maki G, Chow KU, Schimpf A, Klingemann HG, et al. Expression of a CD20-specific chimeric antigen receptor enhances cytotoxic activity of NK cells and overcomes NK-resistance of lymphoma and leukemia cells. Cancer Immunol Immunother (2008) 57:411-23. doi:10.1007/ s00262-007-0383-3

100. Boissel L, Betancur M, Lu W, Wels WS, Marino T, Van Etten RA, et al. Comparison of mRNA and lentiviral based transfection of natural killer cells with chimeric antigen receptors recognizing lymphoid antigens. Leuk Lymphoma (2012) 53:958-65. doi:10.3109/10428194.2011.634048

101. Boissel L, Betancur-Boissel M, Lu W, Krause DS, Van Etten RA, Wels WS, et al. Retargeting NK-92 cells by means of CD19- and CD20-specific chimeric antigen receptors compares favorably with antibody-dependent cellular cytotoxicity. Oncoimmunology (2013) 2:e26527. doi:10.4161/onci.26527

102. Liu H, Yang B, Sun T, Lin L, Hu Y, Deng M, et al. Specific growth inhibition of ErbB2-expressing human breast cancer cells by genetically modified NK92 cells. Oncol Rep (2015) 33:95-102. doi:10.3892/or.2014.3548

103. Schonfeld K, Sahm C, Zhang C, Naundorf S, Brendel C, Odendahl M, et al. Selective inhibition of tumor growth by clonal NK cells expressing an ErbB2/HER2-specific chimeric antigen receptor. Mol Ther (2015) 23:330-8. doi: $10.1038 / \mathrm{mt} .2014 .219$

104. Uherek C, Tonn T, Uherek B, Becker S, Schnierle B, Klingemann HG, et al. Retargeting of natural killer-cell cytolytic activity to ErbB2-expressing cancer cells results in efficient and selective tumor cell destruction. Blood (2002) 100:1265-73.

105. Miller JS, Soignier Y, Panoskaltsis-Mortari A, McNearney SA, Yun GH, Fautsch SK, et al. Successful adoptive transfer and in vivo expansion of human 
haploidentical NK cells in patients with cancer. Blood (2005) 105:3051-7. doi:10.1182/blood-2004-07-2974

106. Yang B, Liu H, Shi W, Wang Z, Sun S, Zhang G, et al. Blocking transforming growth factor-beta signaling pathway augments anti-tumor effect of adoptive NK-92 cell therapy. Int Immunopharmacol (2013) 17:198-204. doi:10.1016/j. intimp.2013.06.003

107. Genßler S, Burger MC, Zhang C, Oelsner S, Mildenberger I, Wagner M, et al. Dual targeting of glioblastoma with chimeric antigen receptor-engineered natural killer cells overcomes heterogeneity of target antigen expression and enhances anti-tumor activity and survival. Oncoimmunology (2016) 5:e1119354. doi:10.1080/2162402X.2015.1119354
Conflict of Interest Statement: The authors declare that the research was conducted in the absence of any commercial or financial relationships that could be construed as a potential conflict of interest.

Copyright $\odot 2016$ Shevtsov and Multhoff. This is an open-access article distributed under the terms of the Creative Commons Attribution License (CC BY). The use, distribution or reproduction in other forums is permitted, provided the original author(s) or licensor are credited and that the original publication in this journal is cited, in accordance with accepted academic practice. No use, distribution or reproduction is permitted which does not comply with these terms 